Економічні науки: збірник наукових праць Луцького національного технічного університету. Серія "Регіональна економіка". Випуск 18 (71). Редкол.: відп. ред. д.е.н., професор Л.Л. Ковальська. Луцьк: ІВВ Луцького НТУ, 2021. 278 с.

УДК: 331.52

Чмут А.В., к.е.н, старша викладачка

Херсонський державний університет

\title{
СТАН ТА ТЕНДЕНЦІЇ РОЗВИТКУ РИНКУ ПРАЦІ ХЕРСОНСЬКОÏ ОБЛАСТІ
}

В статті представлено аналіз стану та тенденцій розвитку ринку праці Херсонської області на основні статистичних даних за 2020 рік. Під час аналізу ситуації на ринку праці висвітлені дані щодо обсягів робочої сили, кількості зайнятих i безробітних у динаміці. Проаналізовано галузеву структуру зайнятих, рівень заробітної плати та попит на працю.

Ключові слова: ринок праці, зайнятість, робоча сила, безробіття, заробітна плата.

\section{Chmut A. \\ POSITION AND TRENDS OF LABOR MARKET DEVELOPMENT IN KHERSON REGION}

The labor market is an important indicator of economic development of the country as a whole and its regions. In recent years, the Ukrainian labor market has seen an imbalance between supply and demand, which was the result of external factors: the socio-economic situation in the country, the international situation, state policy of labor market regulation, and since 2019 the COVID-19 pandemic has had its full impact. Given the trends of changes in the internal and external environment of the market, the analysis of trends in its development is a necessary tool for making operational management decisions at both state and local levels. The labor market of Kherson region is a component of the national labor market of Ukraine. Taking into account the views of researchers, the essence of the regional labor market can be defined as a system of relations between employers, employees and state and social partners to create conditions, distribution, exchange and use of labor in a particular region. The main function of the regional labor market is to provide all employers with the necessary labor force. In order to analyze the situation on the labor market, it is necessary to study its socio-economic indicators on the basis of existing statistics. The article presents an analysis of the state and trends of the labor market of Kherson region on the basis of fundamental statistical data for 2020 . During the analysis of the situation on the labor market, data on the volume of labor force, the number of employed and unemployed in the dynamics are highlighted. The sectoral structure of employees, the level of wages and labor demand are analyzed.

The analysis of the labor market of Kherson region revealed a number of problems, including the growth of the number of unemployed, the growth of the 
Економічні науки: збірник наукових праць Луцького національного технічного університету. Серія "Регіональна економіка". Випуск 18 (71). Редкол.: відп. ред. д.е.н., професор Л.Л. Ковальська. Луцьк: ІВВ Луцького НТУ, 2021. 278 с.

share of the unemployed in the region's labor force, reduction of labor force, low levels of average nominal wages, overall reduction of vacancies. The labor market in the region needs to be regulated taking into account existing trends, which should be aimed at increasing jobs, raising wages and overall economic development of the region.

Key words: labor market, employment, labor force, unemployment, wages.

Чмут А.В.

\section{СОСТОЯНИЕ И ТЕНДЕНЦИИ РАЗВИТИЯ РЫНКА ТРУДА ХЕРСОНСКОЙ ОБЛАСТИ}

В статье представлен анализ состояния и тенденций развития рынка труда Херсонской области на основные статистических данных 2020 года. При анализе ситуации на рынке труда освещены данные касательно количества рабочей силы, занятых и безработных в динамике. Проанализировано отраслевую структуру занятых, уровень заработной платы и спрос на труд.

Ключевые слова: рынок труда, занятость, рабочая сила, безработица, заработная плата.

\section{Постановка проблеми у загальному вигляді та ії} зв'язок з важливими науковими і практичними завданнями.

Ринки факторів виробництва $є$ важливими складовими ринкової економіки. Будучи похідними від ринків товарів i послуг вони є невід'ємним елементом ринкового механізму. Особливої уваги заслуговує ринок праці, адже наразі саме він в багатьох аспектах є індикатором розвитку економіки країни в цілому та іï регіонів. Останні роки на ринку праці України спостерігається дисбаланс між попитом і пропозицію, який в тому числі став результатом дії зовнішніх факторів: соціальноекономічного стану в країні, міжнародної ситуації, державної політики регулювання ринку праці, а з 2019 року всій вплив завдала пандемія COVID-19. Враховуючи тенденції до змін внутрішнього та зовнішнього середовища функціонування ринку, аналіз тенденцій його розвитку $\epsilon$ необхідним інструментом для прийняття оперативних управлінських рішень, як на державному, так і на локальному рівнях.

Аналіз останніх досліджень у яких започатковано вирішення проблеми. Теоретичні та практичні аспекти аналізу вітчизняного ринку праці знайшли відображення у 
Економічні науки: збірник наукових праць Луцького національного технічного університету. Серія "Регіональна економіка". Випуск 18 (71). Редкол.: відп. ред. д.е.н., професор Л.Л. Ковальська. Луиьк: ІВВ Луцьького НТУ, 2021. 278 с.

дослідженнях: Д.Богині, А.Колота, І.Гнатенко, В. Федоренко, Л. Федунчик.

Цілі статті. Аналіз стану та тенденцій розвитку ринку праці Херсонської області.

Виклад основного матеріалу дослідження 3 повним обгрунтуванням отриманих наукових результатів. Ринок праці Херсонської області є складовою національного ринку праці України. 3 урахуванням поглядів дослідників сутність регіонального ринку праці можна визначити як систему відносин між роботодавцями, найманими працівниками та державно-соціальними партнерами 3 питань створення умов, розподілу, обміну і використання робочої сили на території певного регіону [1]. Головною функцією регіонального ринку праці є забезпечення всіх суб'єктів господарювання необхідною робочою силою [2].

Для того, щоб провести аналіз кон'юнктури ринку праці, необхідно дослідити його соціально-економічні показники на підставі існуючих статистичних даних. Варто зазначити, що ринок робочої сили Херсонської області займає 2,7\% від загальноукраїнського [3].Розподіл населення за статусом участі у складі робочої сили представлено в табл. 1.

Таблиця 1

Розподіл населення за статусом участі у складі робочої сили Херсонської області, тис осіб [4]

\begin{tabular}{|l|r|r|r|r|r|r|r|}
\hline \multirow{2}{*}{ Показники } & \multicolumn{5}{|c|}{ Роки } & \multicolumn{2}{c|}{$\begin{array}{c}\text { Темп } \\
\text { Приросту, \% }\end{array}$} \\
\cline { 2 - 9 } & 2010 & 2015 & 2018 & 2019 & 2020 & $\begin{array}{c}2020 / \\
2010 \\
\text { p.p. }\end{array}$ & $\begin{array}{c}2020 / \\
2019 \\
\text { p.p. }\end{array}$ \\
\hline Робоча сила & 534,9 & 496,6 & 499,5 & 503,8 & 490,1 & $-8,4$ & $-2,7$ \\
\hline Зайняті & 488,8 & 445,8 & 448,2 & 455,3 & 434,5 & $-11,1$ & $-4,6$ \\
\hline $\begin{array}{l}\text { Безробітні } \\
\text { складі рогогітнх у } \\
\text { сили }\end{array}$ & 46,1 & 50,8 & 51,3 & 48,5 & 55,6 & 20,6 & 14,6 \\
\hline
\end{tabular}


Економічні науки: збірник наукових праць Луцького національного технічного університету. Серія "Регіональна економіка". Випуск 18 (71). Редкол.: відп. ред. д.е.н., професор Л.Л. Ковальська. Луцьк: ІВВ Луцького НТУ, 2021. 278 с.

Динаміка представлених показників демонструє негативні тенденції. Підвищення частки безробітних на фоні зниження кількості робочої сили свідчить про несприятливу ситуацію на ринку праці. В структурі безробітних у 2020 році 56\% становили жінки і 44\% - чоловіки. Аналіз безробітних за типом місцевості показав, що в їх структурі 64,2\% булі жителями міської місцевості. Середня тривалість пошуку роботи у 2020 році становила 5 місяців.

Зайнятість населення за видами економічної діяльності представлена на рис.1

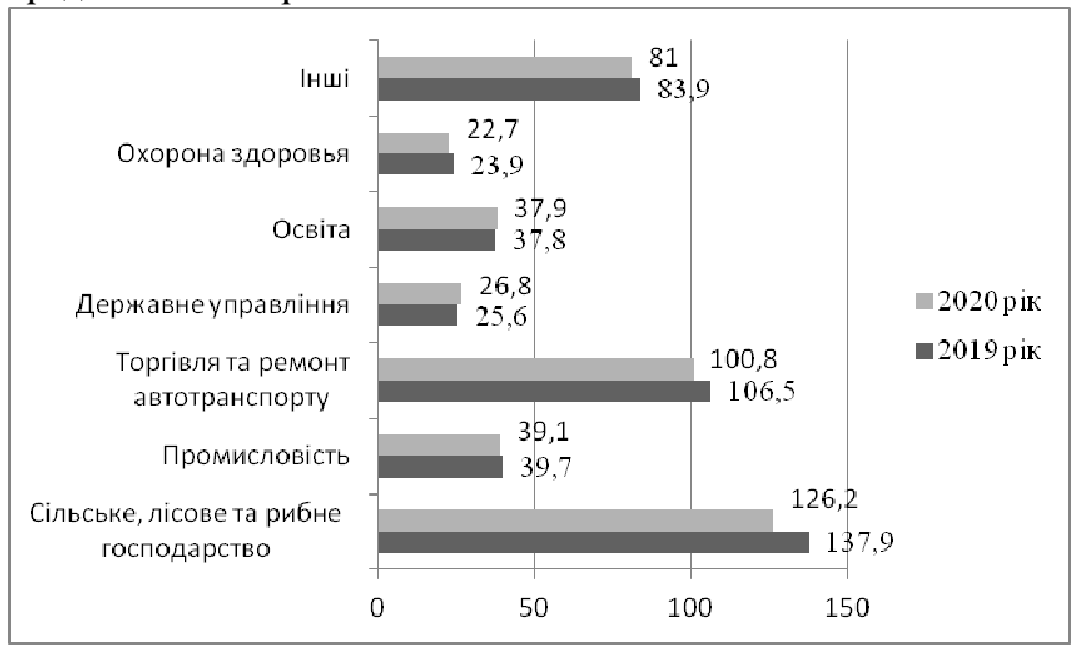

Рис.1. Зайнятість населення за окремими видами економічної діяльності, тис осіб [4].

На рис. 1 представлені галузі 3 найбільшою часткою зайнятих, серед них помітно виділяються галузь сільського господарства та торгівлі.

Середньооблікова кількість штатних працівників у 2020 році становила 146,9 тис. осіб. В розрізі галузей найбільша кількість 35,7 тис осіб відповідає галузі освіти, 20,6 тис осіб охороні здоров'я, 24,8 тис осіб - промисловості, 15,4 тис. осіб сільському, лісовому та рибному господарству [4]. 
Економічні науки: збірник наукових праць Луцького національного технічного університету. Серія "Регіональна економіка". Випуск 18 (71). Редкол.: відп. ред. д.е.н., професор Л.Л. Ковальська. Луцьк: ІВВ Луцького НТУ, 2021. 278 с.

Важливим аспектом аналізу ринку праці є аналіз вартості праці в регіоні, зокрема динаміки середньої заробітної плати (рис.2.). В 2020 році середня номінальна заробітна плата зросла в порівнянні 3 попереднім періодом на 14, 3 \% і склала 9354 грн., в той же час в середньому по Україні цей показник склав 11591,15 грн [5]. Ріст реальної заробітної плати в Херсонській області склав 11,3\%[4].

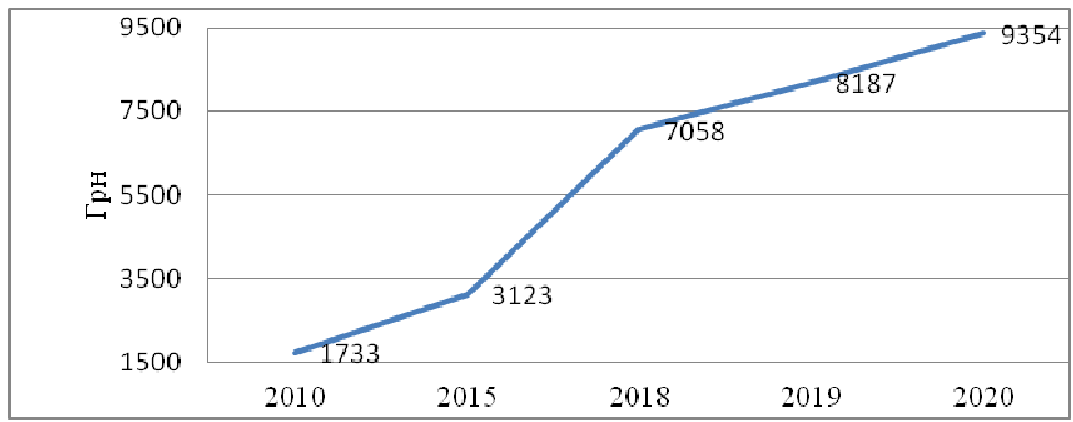

Рис 2. Середня номінальна заробітна плата в Херсонській області по роках [4].

Необхідно відмітити, що заробітну плату в межах 5000 грн отримували у 2020 році 7,7\% працівників, в межах 5000-6000 грн - 19,3\% працівників, 6000-10000 грн - 31,3\% працівників, 10000-15000 грн - 20,2\% працівників, понад 15000 - 21,5\% працівників.

Майже на 7\% в структурі зросла частка працівників, які отримують більше 15 тис грн заробітної плати в порівнянні 3 попереднім періодом.

Найбільші зарплати у сфері державного управління, фінансової та страхової діяльності, складського господарства та промисловості.

Аналіз ринку праці не буде повним без визначення пропозиції на ньому. Так, в 2020 році в Херсонській обласній службі зайнятості було зареєстровано 17628 вакансій, що складає 66,8\% від попереднього періоду та свідчить про 
Економічні науки: збірник наукових праць Луцького національного технічного університету. Серія "Регіональна економіка". Випуск 18 (71). Редкол.: відп. ред. д.е.н., професор Л.Л. Ковальська. Луиьк: ІВВ Луцьького НТУ, 2021. 278 с.

зменшення попиту на працю. Найбільша кількість вакансій була в галузі сільського господарства - 5706 вакансій, освіти 1066 вакансій, охорони здоров'я - 1301 вакансій та переробної промисловості - 1715 вакансій. За професійними групами найбільш затребуваними були робітники 3 обслуговування, експлуатації та контролювання за роботою технологічного устаткування, складання устаткування та машин 4100 вакансій, найпростіші професії - 3044 вакансій, працівники сфери торгівлі - 2692 вакансії [6]. Зниження попиту на працю, в тому числі висококваліфікованих працівників, зумовлює активну трудову міграцію населення, що в перспективі вкрай негативно позначиться на галузях економіки, а відповідно і на соціально-економічних показниках регіону.

Висновки. Аналіз ринку праці Херсонської області виявив ряд проблем серед яких, ріст чисельності безробітних, ріст частки безробітних у чисельності робочої сили регіону, зменшення кількості робочої сили, низькі рівні середньої номінальної заробітної плати, загальне зменшення кількості вакансій. Ринок праці регіону потребує регулювання 3 урахуванням існуючих тенденцій, яке має бути направлене на збільшення робочих місць, підвищення заробітної плати та загального економічного розвитку області.

\section{Список бібліографічного опису}

1. Монгуш О.С., Ондар О.С. Региональный рынок труда // Экономика и бизнес: теория и практика. 2021. №1-1. URL: https://cyberleninka.ru/article/n/regionalnyy-rynok-truda (дата звернення: 16.10.2021).

2. Лизанець А. Розвиток регіонального ринку праці в контексті євроінтеграційних процесів. URL: http://ird.gov.ua/sep/sep20145(109)/sep20145(109)_213_LyzanetsAH.pdf （дата звернення: 17.10.2021).

3. Робоча сила України. Статистичний збірник URL: http://www.ukrstat.gov.ua/druk/publicat/kat_u/2021/zb/07/zb_r_s_2020.pdf (дата звернення: 17.10.2021).

4. Статистичний щорічник Херсонської області за 2020 рік / За ред. Н.Г.Мельничук. Херсон: Головне управління статистики в Херсонській області, 2021. $403 \mathrm{c}$. 
Економічні науки: збірник наукових праць Луцького національного технічного університету. Серія "Регіональна економіка". Випуск 18 (71). Редкол.: відп. ред. д.е.н., професор Л.Л. Ковальська. Луцьк: ІВВ Луцького НТУ, 2021. 278 с.

5. Праця України у 2020 році. Статистичний збірник. URL: http://www.ukrstat.gov.ua/druk/publicat/kat u/2021/zb/08/zb Pracia2020.pdf (дата звернення: 17.10.2021).

6. Херсонський обласний центр зайнятості. Статистична інформація. URL: https://khe.dcz.gov.ua/analitics/66 (дата звернення: 17.10.2021).

\section{References}

$\begin{array}{ccccc} & \text { 1.Mongush O.S., Ondar } & \text { O.S. Regional'nyj rynok truda // Jekonomika i } \\ \text { biznes: } & \text { teorija } & \mathrm{i} & \text { praktika. } & 2021 .\end{array}$ https://cyberleninka.ru/article/n/regionalnyy-rynok-truda (accessed: 16.10.2021). [in Rusian].

2.Lyzanecj A. Rozvytok reghionaljnogho rynku praci $\mathrm{v}$ konteksti jevrointeghracijnykh procesiv. URL: http://ird.gov.ua/sep/sep20145(109)/sep20145(109)_213_LyzanetsAH.pdf (accessed: 17.10.2021) [in Ukrainian].

3.Robocha syla Ukrajiny. Statystychnyj zbirnyk URL: http://www.ukrstat.gov.ua/druk/publicat/kat_u/2021/zb/07/zb_r_s_2020.pdf (accessed: 17.10.2021) [in Ukrainian].

4.Statystychnyj shhorichnyk Khersonsjkoji oblasti za 2020 rik / Za red. N.Gh.Meljnychuk. Kherson: Gholovne upravlinnja statystyky v Khersonsjkij oblasti, 2021. 403 p. [in Ukrainian].

5.Pracja Ukrajiny u 2020 roci. Statystychnyj zbirnyk. URL: http://www.ukrstat.gov.ua/druk/publicat/kat_u/2021/zb/08/zb_Pracia2020.pdf (accessed: 17.10.2021). [in Ukrainian].

6.Khersonsjkyj oblasnyj centr zajnjatosti. Statystychna informacija URL: https://khe.dcz.gov.ua/analitics/66 (accessed:17.10.2021). [in Ukrainian].

DOI: https://doi.org/10.36910/2707-6296-2021-18(71)-25 